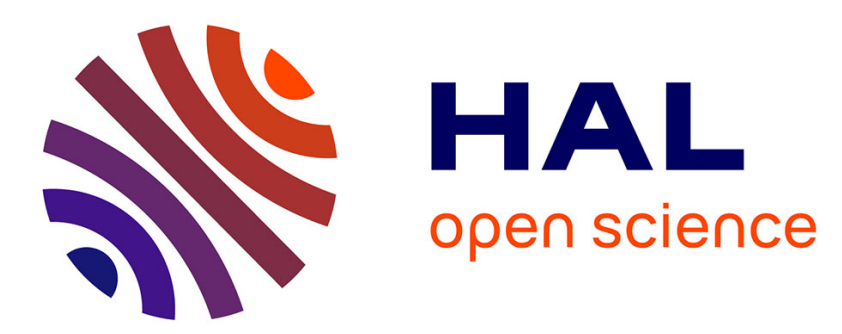

\title{
The tropical giant clam Hippopus hippopus shell, a new archive of environmental conditions as revealed by sclerochronological and $\delta 180$ profiles
}

\author{
A. Aubert, Claire E. Lazareth, Guy Cabioch, Hugues Boucher, T. Yamada, \\ Yasufumi Iryu, Richard Farman
}

\section{To cite this version:}

A. Aubert, Claire E. Lazareth, Guy Cabioch, Hugues Boucher, T. Yamada, et al.. The tropical giant clam Hippopus hippopus shell, a new archive of environmental conditions as revealed by sclerochronological and $\delta 18 \mathrm{O}$ profiles. Coral Reefs, 2009, 28 (4), pp.989 - 998. 10.1007/s00338-009-0538-0 . ird-01697896

\section{HAL Id: ird-01697896 \\ https://hal.ird.fr/ird-01697896}

Submitted on 31 Jan 2018

HAL is a multi-disciplinary open access archive for the deposit and dissemination of scientific research documents, whether they are published or not. The documents may come from teaching and research institutions in France or abroad, or from public or private research centers.
L'archive ouverte pluridisciplinaire $\mathbf{H A L}$, est destinée au dépôt et à la diffusion de documents scientifiques de niveau recherche, publiés ou non, émanant des établissements d'enseignement et de recherche français ou étrangers, des laboratoires publics ou privés. 


\title{
The tropical giant clam Hippopus hippopus shell, a new archive of environmental conditions as revealed by sclerochronological and $\delta^{18} \mathrm{O}$ profiles
}

\author{
A. Aubert · C. E. Lazareth - G. Cabioch $\cdot$ H. Boucher · T. Yamada · Y. Iryu · R. Farman
}

Received: 20 April 2009/Accepted: 29 July 2009/Published online: 26 August 2009

\begin{abstract}
The use of the sclerochronology and geochemistry of a New Caledonian (South West Pacific) giant clam Hippopus hippopus shell as markers of environmental changes has been investigated. Growth increment thickness and $\delta^{18} \mathrm{O}$ ratios were measured on 4 years of shell growth of a modern specimen. During the last year, this giant clam was placed in a tank equipped for high-frequency environmental monitoring. Because shell is secreted in isotopic equilibrium with the seawater, the palaeo-sea surface temperature (SST) equation obtained faithfully reproduces the seasonal SST amplitudes. Growth increment thickness changes are seasonal and, for more than $50 \%$, governed by the SST changes. The transplantation from the in situ site to the tank and reproduction events reduces the strength of growth and SST relationships. Nevertheless, growth increment thickness measurements can give information on average, minimal and maximal past SST in diagenetically altered shells. A peculiar growth event characterized by a
\end{abstract}

Communicated by Geology Editor Dr. Bernhard Riegl

A. Aubert · C. E. Lazareth $(\bowtie) \cdot$ G. Cabioch $\cdot$ H. Boucher IPSL/LOCEAN, UPMC/CNRS/IRD/MNHN, Centre IRD France Nord, 32 avenue Henri Varagnat, 93143 Bondy Cedex, France e-mail: claire.lazareth@ird.fr

\section{T. Yamada}

Institute of Geology and Paleontology, Graduate School of Science, Tohoku University, Sendai 980-8578, Japan

Y. Iryu

Department of Earth and Planetary Sciences, Graduate School of Environmental Studies, Nagoya University, Nagoya 464-8601, Japan

R. Farman

Aquarium des Lagons, B.P. 8185, Nouméa 98807, New Caledonia short, drastic and significant decrease has been identified and attributed to an intense upwelling event. This study further highlights the use of giant clam shell $\delta^{18} \mathrm{O}$ as a SST proxy but also demonstrates that $H$. hippopus growth increment thickness changes provide useful information on past environmental settings and on exceptional events, for example, intense upwellings.

Keywords Tridacnidae $\cdot \delta^{18} \mathrm{O} \cdot$ Sclerochronology . SST $\cdot$ New Caledonia $\cdot$ Upwelling

\section{Introduction}

The climate of the South Western tropical Pacific is strongly influenced by the intraseasonal to interannual fluctuations of the South Pacific Convergence Zone (SPCZ), which plays a significant role in global atmospheric circulation (Vincent 1994). The location of the SPCZ largely determines the surface flow pattern and hydrological cycle in the south Pacific region. Small displacements in the position of the SPCZ can imply drastic changes in precipitation and wind regimes for islands in the South Pacific region. Reconstructing SPCZ fluctuations can therefore provide important information on the regional climate variability. The average location of the southern limit of the SPCZ lies near New Caledonia $\left(22^{\circ} \mathrm{S}, 166^{\circ} \mathrm{E}\right)$, and proxies in this region are therefore likely to reflect to a certain extent the SPCZ variability.

Geochemical analyses of corals have become a standard means to assess environmental variability in the tropical surface oceans (Beck et al. 1992; Gagan et al. 2000; Corrège 2006). Yet recent works have pointed out that their aragonitic skeleton may have been affected by marine and freshwater diagenesis, so that the geochemical data and their 
interpretation in terms of sea surface temperature (SST) and related climatic features must be sometimes regarded with caution (Enmar et al. 2000; Müller et al. 2001; McGregor and Gagan 2003; Quinn and Taylor 2006; Hendy et al. 2007). In similar environments, the bivalves from the Tridacnidae family can be regarded as analogous recorders of environmental conditions (Aharon 1991). In the Pacific, these molluscs were, and are always, commonly used as food and tool supply, so that many shells are found in archaeological sites, often dated of periods of broad interest. In addition, the aragonitic shell of tridacnids is dense (Aharon and Chappell 1986; Watanabe et al. 2004) and less sensitive to diagenetic processes than the coral skeletons (Chappell and Polach 1972). Finally, Tridacnidae have a long lifetime, from 8 to more than 100 years (Rosewater 1965), providing long-term record of the environmental conditions encountered during their growth. Tridacnidae shells are thus a potential, powerful environmental archive that could assess or complement data obtained from coral skeleton.

Previous works devoted to the oxygen stable isotopes $\left(\delta^{18} \mathrm{O}\right)$ composition of Tridacnidae shell revealed that the shell is secreted in isotopic equilibrium with seawater (Aharon 1983, 1991; Aharon and Chappell 1986; Jones et al. 1986; Romanek and Grossman 1989; Watanabe and Oba 1999). Palaeo-SST reconstructions using $\delta^{18} \mathrm{O}$ data from fossil shells have already been obtained (Aharon et al. 1980; Aharon 1983; Aharon and Chappell 1986; Watanabe et al. 2004). Nevertheless, diagenetic alteration can modify the shell geochemistry (Armendáriz et al. 2008; Brigaud et al. 2008) and, in this case, the study of shell growth patterns, i.e., sclerochronology, can give information on the environmental changes during shell growth. Indeed, the mollusc shell growth is characterized by a succession of layers, or increments, which thickness changes and rhythm of deposition are related to various physiological (e.g., reproduction, ontogeny) and environmental parameters (e.g., tidal cycle, water temperature, storm events, food availability), depending on the mollusc species (reviews in Rhoads and Lutz 1980; Richardson 2001). Several authors demonstrated that the growth pattern of Tridacnidae shells is characterized by an alternation of dark/light bands, one couplet representing 1 year of shell growth (Bonham 1965; Aharon and Chappell 1986; Pätzold et al. 1991). Using oxygen stable isotope variations, it was shown that dark bands correspond to winters and light band to summers (Aharon and Chappell 1986; Aharon 1991; Pätzold et al. 1991; Watanabe et al. 2004). The same pattern of summer/winter alternation of light/dark bands is observed here from the sclerochronological record. Moreover, the positive correlation between the seasonality and the H. hippopus shell growth is similar to the field studies results from Lucas et al. (1989) and Ambariyanto (1997). In addition to the seasonal banding in the Tridacnidae shells, high-frequency increments connected to daily growth were observed in Tridacna gigas, T. maxima, T. squamosa and Hippopus hippopus (Bonham 1965; Pannella and MacClintock 1968; Henocque 1980; Aharon and Chappell 1986; Pätzold et al. 1991; Watanabe and Oba 1999; Watanabe et al. 2004). In his work on T. gigas, Bonham (1965) observed that the daily increments are thinner in the black (winter) than in the light (summer) bands. Such shell growth variation in the Tridacnidae in relation to the seasonality was confirmed by studies dedicated to giant clam culture improvements. Indeed, higher shell growth rates during summers where observed for T. gigas and T. maxima (Lucas et al. 1989; Ambariyanto 1997). Then, Pätzold et al. (1991) assumed that the daily increment thickness in T. gigas depends on seasonal SST changes, while Watanabe and Oba (1999) interpreted these ones in H. hippopus as reflecting the amount of solar radiation received. It has been shown that the SST changes, from the daily to the seasonal scales, are one of the major factors that influence the increment width variations in many mollusc species (Barker 1964; Rhoads and Pannella 1970; Jones 1983; Goodwin et al. 2001; Richardson 2001; Schöne et al. 2005b). Sclerochronology would be thus a new reliable tool for palaeo-SST reconstructions. However, at this day, no extensive sclerochronological study was dedicated to the use of the of Tridacnidae daily increments thickness changes as SST proxy. The aim of this study is to provide data on the reliability of the $H$. hippopus shell $\delta^{18} \mathrm{O}$ and growth increment thickness variations as recorders of SST and environmental changes.

\section{Materials and methods}

\section{Field sampling}

In May 2003, a living H. hippopus (Tridacnidae; Linné, 1758) was collected at $2 \mathrm{~m}$ water depth, at Ducos Island in the Bay of Saint Vincent in New Caledonia $\left(166^{\circ} \mathrm{E}, 21^{\circ} 60\right.$ S) (Fig. 1). The specimen was then placed in a 1-m-depth tank at the "Aquarium des Lagons", Noumea. The tank was placed outside, partly sheltered from sun only at the end of day by low-roofed buildings. The tank seawater was continuously supplied from the "Baie des Citrons" situated close to the aquarium. Finally, the H. hippopus specimen was collected on the 19 July 2004 after 14.5 months of growth in the aquaculture tank. The shell is of $22.5 \mathrm{~cm}$ long and $14 \mathrm{~cm}$ height (umbo-margin) (Fig. 2a).

Methods

\section{Sample preparation}

The shell was cut in several $\sim 1.5$-mm-thick slices with an ISOMET 5000 (Buehler ${ }^{\circledR}$ ) diamond saw, along the 
Fig. 1 Location of: 1. The sampling site of the modern Hippopus hippopus, the Ducos Island in the Baie of St.-Vincent (New Caledonia), 2. The Tontouta Météo France station, 3. The Uitoë monitoring station, 4. The Aquarium des Lagons (abbreviated "Aquarium" on the Figure) and 5. The "Baie des Citrons

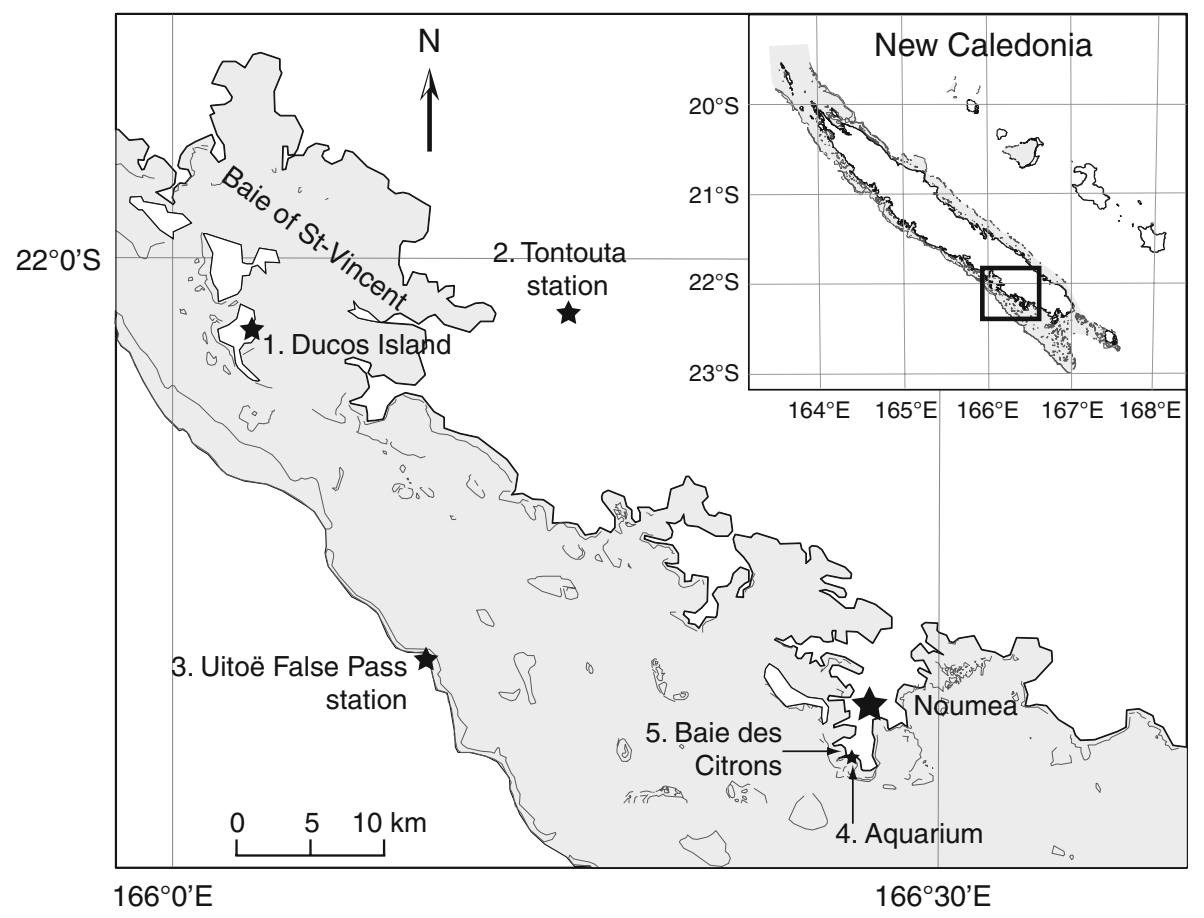

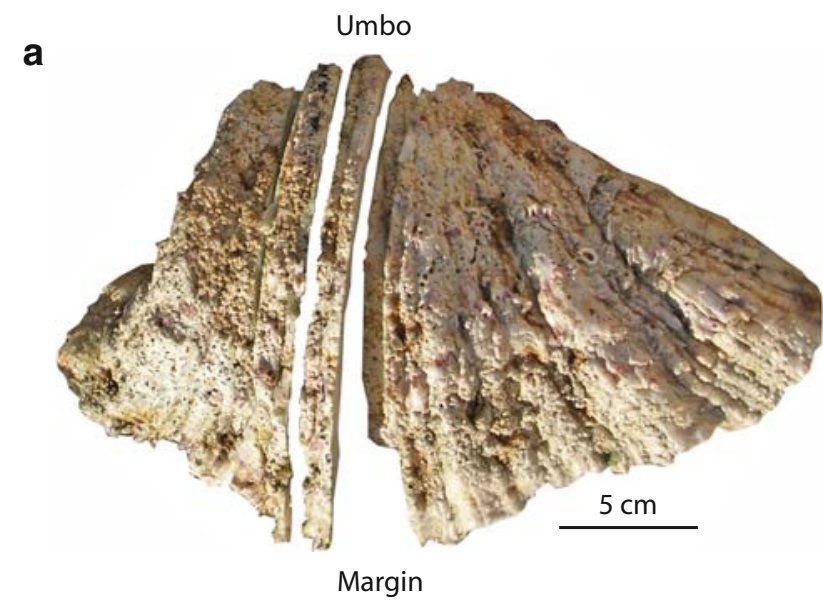

b

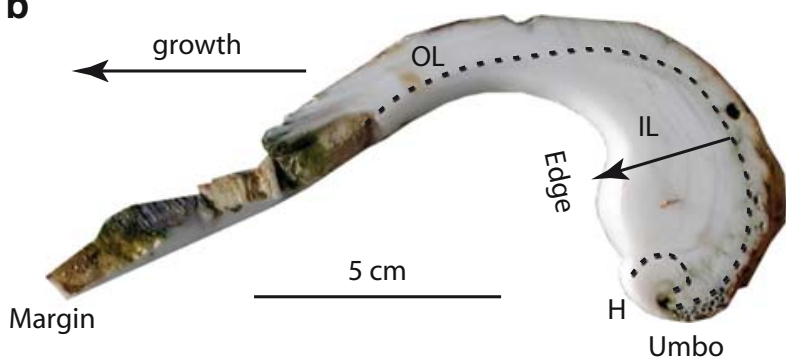

Fig. 2 Shell of the Hippopus hippopus specimen. a Location of the slab studied. b Transversal cross-section showing the different shell parts; outer layer $(O L)$, inner layer $(I L)$ and hinge area $(H)$. Arrows show the direction of growth

maximum growth axis (Fig. 2a). The Tridacnidae shell, made of aragonite (Bonham 1965; Pätzold et al. 1991), is composed of three parts: the inner layer, the outer layer and the hinge area (Pannella and MacClintock 1968; Pätzold et al. 1991). The inner layer is characterized by a prismatic microstructure and the outer layer and the hinge area by a crossed-lamellar microstructure. In our transversal crosssections, the three areas were clearly evidenced (Fig. 2b). To analyse the environmental changes at an infra-monthly resolution, the shell part with the highest growth rate should be selected, i.e., the outer layer. The sclerochronological and geochemical analyses were performed in the inner layer in which the growth pattern can be easily analysed. In this study, the younger part of the inner layer, which was in contact with the animal body, will be named the shell edge (Fig. 2b).

The sections were first polished with 70,50 and $15 \mu \mathrm{m}$ diamond discs and then with 6 and $3 \mu \mathrm{m}$ diamond powders. Ultra sin bath was used in between the two diamond powders to eliminate remaining diamond particles.

\section{Sclerochronological methodology}

Etching technique was used to point up the growth increments. To define the better procedure, several tests were performed using three different solutions, acetic acid $10 \%$, hydrochloric acid 5\% and the Mutvei's solution (Schöne et al. 2005a). Various etching time-lengths were tested with each solution. Increments were better observed after $45 \mathrm{~min}$ of etching in a slightly modified Mutvei's solution characterized by $500 \mathrm{~mL}$ glutaraldehyde $25 \%, 500 \mathrm{~mL}$ acetic acid $1 \%$ and $0.1 \mathrm{~g}$ of alcian blue powder. 
The Mutvei's solution preferentially preserves layers richer in organic matrix. This gives a peculiar morphology marked by a succession of ridges and grooves. Because the ridges are easily identified, one growth increment was defined as the interval between each ridge. The pattern observed is perfectly similar to the one obtained by Watanabe and Oba (1999) who said that it results of "daily growth lines" (Fig. 1d in Watanabe and Oba 1999). Slightly overlapping pictures of the whole inner layer were taken under the optical microscope using diffused light with a magnification of 100 . Then, a sclerochronological software was used (modified version of Analysis Visilog basic ${ }^{\circledR}$ V. 6.841, Noesis) for increment thickness measurements. A tag is placed on each ridge along a stroke drew following the growth axis, and the distance between each tag is automatically calculated. Increment thickness changes were measured from the recent part (edge $=0 \mathrm{~mm}$ ) towards the ancient part of the inner layer (i.e., the limit with the outer layer). The oldest increments, i.e., the last $1.5 \mathrm{~mm}$ of the inner layer, were not clearly highlighted, and their thicknesses were not measured.

\section{Stable isotopic analyses}

Samples for oxygen stable isotope measurements were taken on a second slide of the shell, in direct contact with the one where increment thicknesses were measured. Each sample was obtained using a computer-controlled micromill device (Merchantek ${ }^{\circledR}$ ), parallel to growth increments. Samples were taken from the edge towards the youngest portion of the shell, perpendicular to shell growth. The last sample was taken at $1.7 \mathrm{~mm}$ from the limit between the inner and the outer shell layer. To ensure a sufficient resolution of the $\delta^{18} \mathrm{O}$ record for the shell part that grew in the aquaculture tank (first $8 \mathrm{~mm}$ from the edge), samples were drilled as continuously as possible. For those $8 \mathrm{~mm}$, the distance between each sample is on average of $100 \mu \mathrm{m}$. For the oldest part of the shell, the distance between each sample is of $350 \mu \mathrm{m}$ on average that reduces the duration of the analyses but still allows catching the seasonal signal. The grooves have an average thickness of $80 \mu \mathrm{m}$ providing samples of $50-100 \mu \mathrm{g}$. In each groove, the number of increments was counted to estimate the time-span taken into account for every sample. A groove comprises 3-27 increments depending on the shell growth rate, with an average of 8 increments.

Powders were reacted with $100 \%$ orthophosphoric acid at $75^{\circ} \mathrm{C}$ in a Kiel Carbonate III preparation device, and the resulting $\mathrm{CO}_{2}$ was analysed on a Thermo Electron Delta + Advantage $\left({ }^{\circledR}\right)$ stable isotope ratio mass spectrometer at the Wolfson Laboratory from the School of Geoscience, Edinburgh. The $\delta^{18} \mathrm{O}$ standard deviation for nine analyses of a marble powder (MAB2B), run as a sample over the same period as the shell samples (5 days), was of $\pm 0.06 \%$. $\delta^{18} \mathrm{O}$ values are quoted relative to PDB. The $\delta^{18} \mathrm{O}$ time-series was obtained by comparing the $\delta^{18} \mathrm{O}$ results with the SST data, choosing tie-points carefully; essentially considering winter/summer points (see "Results" for complete description).

\section{Instrumental data}

In the tank, the SSTs and sea surface salinities (SSS) were recorded every $10 \mathrm{~min}$. Unfortunately, the SSS tank logger had a dysfunction, so that the monitored data are aberrant (going down to $31 \mathrm{PSU}$ ) and cannot be used. The average SST recorded from May 2003 to July 2004 is of $24.4 \pm 2.3^{\circ} \mathrm{C}$ with a minimum of 20.5 and a maximum of $29.8^{\circ} \mathrm{C}$. Regarding the period covering the growth range in situ (before May 2003), the SST and SSS series recorded by the closest monitoring station, Uitoé, were selected. The average SST at Uitoé from May 2000 to May 2003 is of $24.1 \pm 1.7^{\circ} \mathrm{C}$ with a minimum and maximum of 20.5 and $29.4^{\circ} \mathrm{C}$, respectively (Fig. 3). During the whole period (in situ + tank), SST ranged between 20.5 and $29.9^{\circ} \mathrm{C}$ with an average of $24.3 \pm 1.8^{\circ} \mathrm{C}$. The SSS record reveals an abrupt decrease from 22 April 2003 to 25 December 2003 due to a technical problem of the sensor. These data were not taken
Fig. 3 Sea surface temperature (SST) and salinity (SSS) instrumental records for the period of shell growth. Uitoé SST record (dark line) from 01 April 2000 to 23 April 2003 and tank SST record (black points) from 24 April 2003 to 19 July 2004. SSS record (grey line) is from the Uitoë station

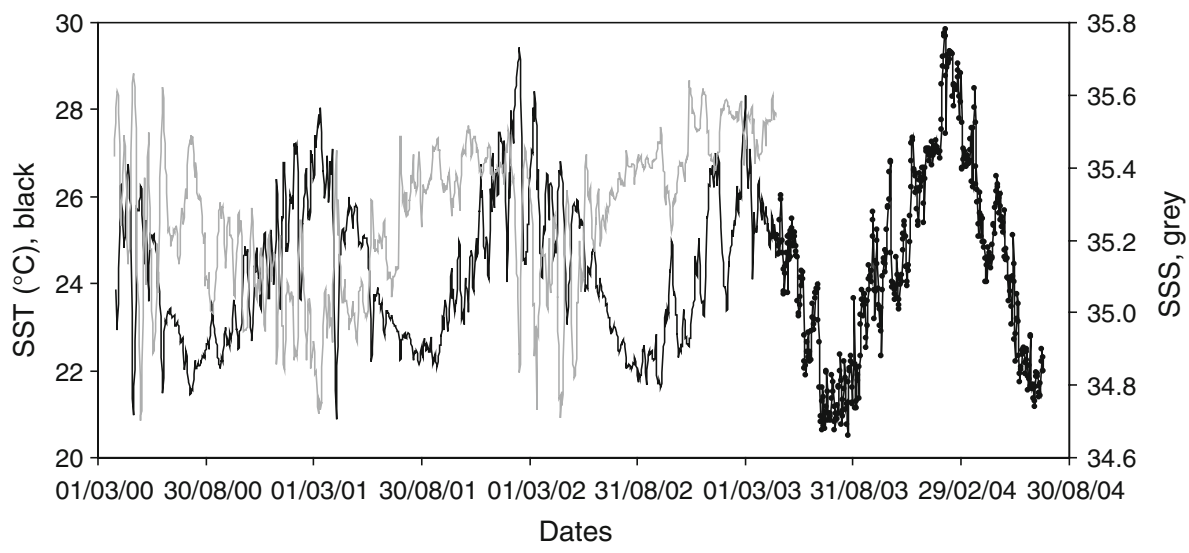


into account in this study. At Uitoé, from May 2000 to the 22 April 2003, the SSS is comprised between 34.7 and 35.7 with an average of $35.3 \pm 0.2$. Wind force and direction for the Tontouta station, near Ducos Island (Fig. 1), were provided by Météo France Nouvelle-Calédonie.

To compare the shell $\delta^{18} \mathrm{O}\left(\delta^{18} \mathrm{O}_{\text {shell }}\right)$ and the SST/SSS records, the SST/SSS data were averaged over several days for each $\delta^{18} \mathrm{O}_{\text {shell }}$ sample. The amount of days chosen corresponds to the number of increments counted inside the groove of each $\delta^{18} \mathrm{O}_{\text {shell }}$ sample. The date assigned to the averaged SST/SSS is that of the middle of the corresponding groove. A $\delta^{18} \mathrm{O}$ value for the seawater $\left(\delta^{18} \mathrm{O}_{\mathrm{SW}}\right)$ was calculated from the averaged SSS data using the following equation:

$\delta^{18} \mathrm{O}_{\mathrm{sw}}=0.255 \times \mathrm{SSS}-8.5353$

corrected from Ourbak et al. (2006, personal communication) using SSS and $\delta^{18} \mathrm{O}_{\mathrm{SW}}$ data measured at the Amédée Lighthouse.

\section{Results}

$\delta^{18} \mathrm{O}_{\text {shell }}$ time-series and palaeo-SST equation calculation

The oxygen stable isotopes of the Tridacnidae shells are in isotopic equilibrium with the seawater. The $\delta^{18} \mathrm{O}_{\text {shell }}$ values, presented in reversed scale for a better comparison with the instrumental SST data, range from -1.44 to $0.52 \%$ with an average of $-0.6 \%$ (Fig. 4). Four seasonal cycles, characterized by steeper increases than decreases, are observed (labelled 1-4 on Figs. 4, 5). The cycle 3 shows two highs up (arrows, Fig. 4).

To assign calendar dates to the $\delta^{18} \mathrm{O}_{\text {shell }}$ record, tiepoints between the $\delta^{18} \mathrm{O}_{\text {shell }}$ and the SST data were carefully selected. The earlier (i.e., further from the edge) maxima $\delta^{18} \mathrm{O}_{\text {shell }}$ of each cycle was attributed to the corresponding SST minima, knowing that the first winter recorded before the collection date (19 July 2004) is the 2003-2004 one. The correspondence between cycles and years is thus as follows: cycle 1 from winter 2000 to 2001; cycle 2 from winter 2001 to 2002; cycle 3 from winter 2002 to 2003 and cycle 4 for winter 2003 (Fig. 5a). Then, summer tie-points were attributed to cycles $1 ; 2$ and 4 . Because the cycle 3 shows two peaks, summer tie-point cannot be attributed for this cycle. For the cycles 1 and 4 , the first $\delta^{18} \mathrm{O}_{\text {shell }}$ minima were attributed to the SST maxima of the corresponding year. For the cycle 2, three $\delta^{18} \mathrm{O}_{\text {shell }}$ minima close to each other are observed. The second $\delta^{18} \mathrm{O}_{\text {shell }}$ minimum was assigned to the SST maximum of 2002. In addition, three significant abrupt $\delta^{18} \mathrm{O}_{\text {shell }}$ increases were correlated to abrupt SST decreases (Fig. 5a; stars). The dates in between the tie-points and at the beginning and ending of the record were linearly interpolated. The time-series shows that $\delta^{18} \mathrm{O}_{\text {shell }}$ is well correlated with SST. From January 2002 to August 2003, the relationship between $\delta^{18} \mathrm{O}_{\text {shell }}$ and SST is less accurate. The second $\delta^{18} \mathrm{O}_{\text {shell }}$ peak of the 2003 summer (arrow on Fig. 5a) occurs in May 2003 which is the period of removal of the H. hippopus from its natural setting into the tank.

The linear regression between SSTs (averaged as explained in "Instrumental data") and $\left(\delta^{18} \mathrm{O}_{\text {shell }}-\delta^{18} \mathrm{O}_{\mathrm{SW}}\right)$ from May 2000 to April 2003 (corresponding also to the period of availability of recorded SSS) gives the following equation:

$$
\begin{aligned}
\mathrm{SST}= & 21.40-2.87\left(\delta^{18} \mathrm{O}_{\text {shell }}-\delta^{18} \mathrm{O}_{\mathrm{sw}}\right) ; \\
& r^{2}=67 \% ; p<0.001 .
\end{aligned}
$$

The equation between $\delta^{18} \mathrm{O}_{\text {shell }}$ and SST is very similar to that obtained by Watanabe and Oba (1999) but characterized by a lower regression coefficient. When
Fig. $4 \delta^{18} \mathrm{O}_{\text {shell }}$ ratio and growth increment thickness changes in the inner layer of the Hippopus hippopus in millimetres from the edge. The numbers and the letters correspond respectively to the cycles and to the peculiar events discussed in the text

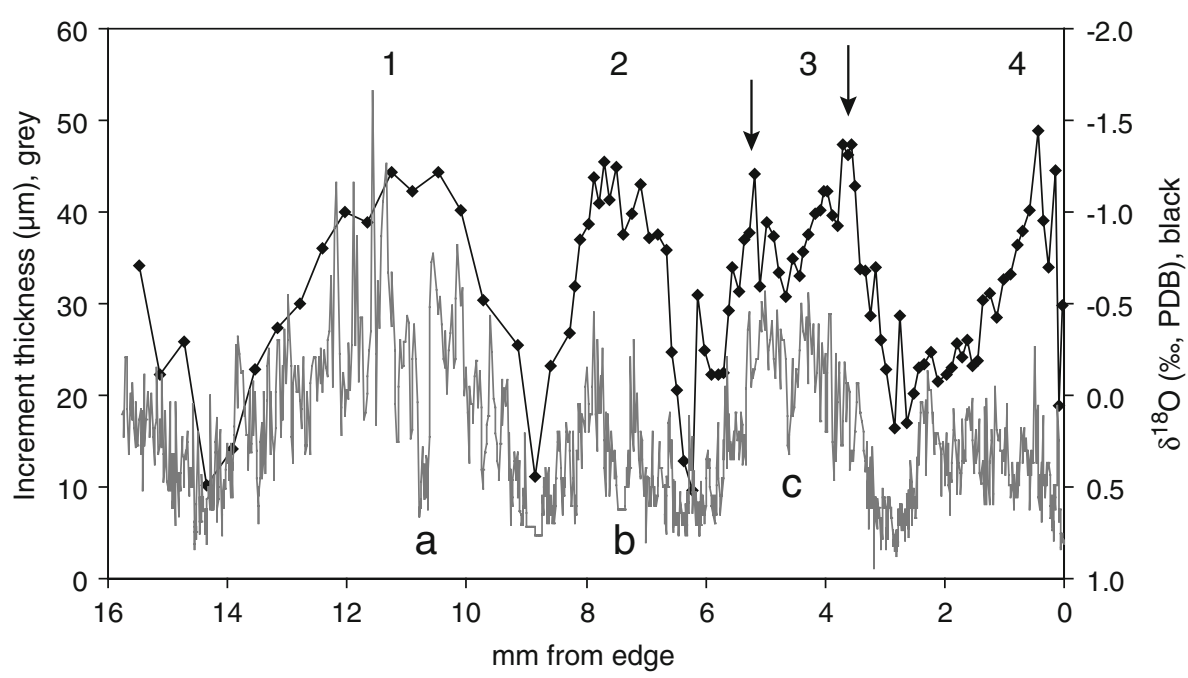


Fig. 5 Time-series of the Hippopus hippopus shell data and of the SST instrumental record (one profile, combination of the Uitoé and the tank data). The numbers correspond to the cycles discussed in the text. a $\delta^{18} \mathrm{O}_{\text {shell }}$ and SST; white circles: winter and summer tiepoints; white crosses: peculiar significant tie-points. b Growth increment thickness and SST.

The letters correspond to the peculiar events discussed in the text
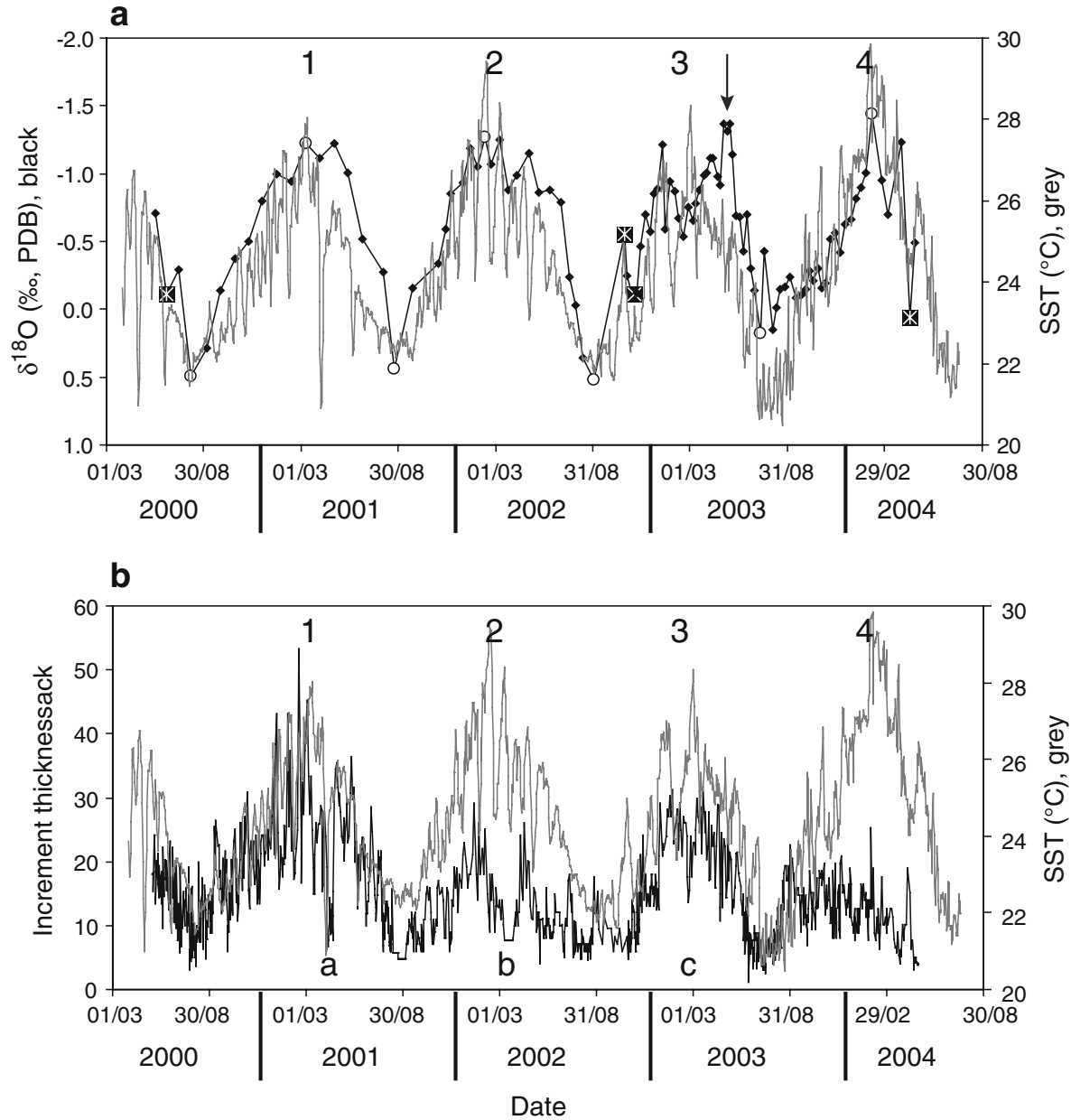

calculated from winter to winter, $r^{2}$ are of $83 \%(00-01)$, $78 \% \quad(01-02), 44 \% \quad(02-03)$ and 67\% (03-04) (all $p<0.001)$. Calculated SSTs for the 2000-2003 period using the above equation reproduce well the mean measured seasonal SST amplitude (winter to summer). Differences between instrumental and calculated seasonal SST amplitudes are of $0.44 ; 1.04$ and $0.70^{\circ} \mathrm{C}$ for the winter-summer seasons 2000-2001, 2001-2002 and 20022003 respectively. The same calculations using the Watanabe and Oba's equation (1999) give amplitude differences of $1.15,0.23$ and $2.37^{\circ} \mathrm{C}$.

\section{Sclerochronological record}

The sclerochronological record includes 1,200 increments which thicknesses ranged from 1.1 to $53.3 \mu \mathrm{m}$ and averaged at $13.2 \pm 7.0 \mu \mathrm{m}$. These results are in good agreement with previously reported daily growth of that species (see review in Klumpp and Griffiths 1994). Four cycles of increase and decrease, numbered in the same way that for the $\delta^{18} \mathrm{O}_{\text {shell }}$ profile, are observed. The cycles are separated by more or less narrow zones of very thin increments at
$10.5,7.5$ and $4.5 \mathrm{~mm}$ from the edge (labelled a-c on Fig. 4). The amplitudes of the second and fourth cycles are lower than that of the first and third. When plotted in $\mathrm{mm}$ from the edge, the increment thickness and the $\delta^{18} \mathrm{O}_{\text {shell }}$ variations are inversely correlated (Fig. 4). This relation implies that the $H$. hippopus increment thickness changes are at least partly linked to SST variations.

A calendar date was assigned to each increment using the $\delta^{18} \mathrm{O}_{\text {shell }}$ time-series. Each $\delta^{18} \mathrm{O}_{\text {shell }}$ sample is identified by both its position from the edge (in $\mathrm{mm}$, middle of the groove) and its calendar date (cf. \& 3.1). We allotted to each increment located at the same position than a $\delta^{18} \mathrm{O}_{\text {shell }}$ sample, the date of the $\delta^{18} \mathrm{O}_{\text {shell }}$ of the corresponding sample. The dates in between each dated increment were linearly interpolated.

The comparison between the sclerochronological timeseries and the SST record shows that the large increments of light bands correspond to the summers and the thin increments of main dark bands to the winters (Fig. 5b). However, the positive correlation between shell growth and SST is not consistent over the whole record. Linear regressions were performed from winter to winter. The 
Fig. 6 SST reconstructed from the equation deduced from the time-series of Hippopus hippopus shell growth increment thickness changes (black) compared to the instrumental SST record (grey)

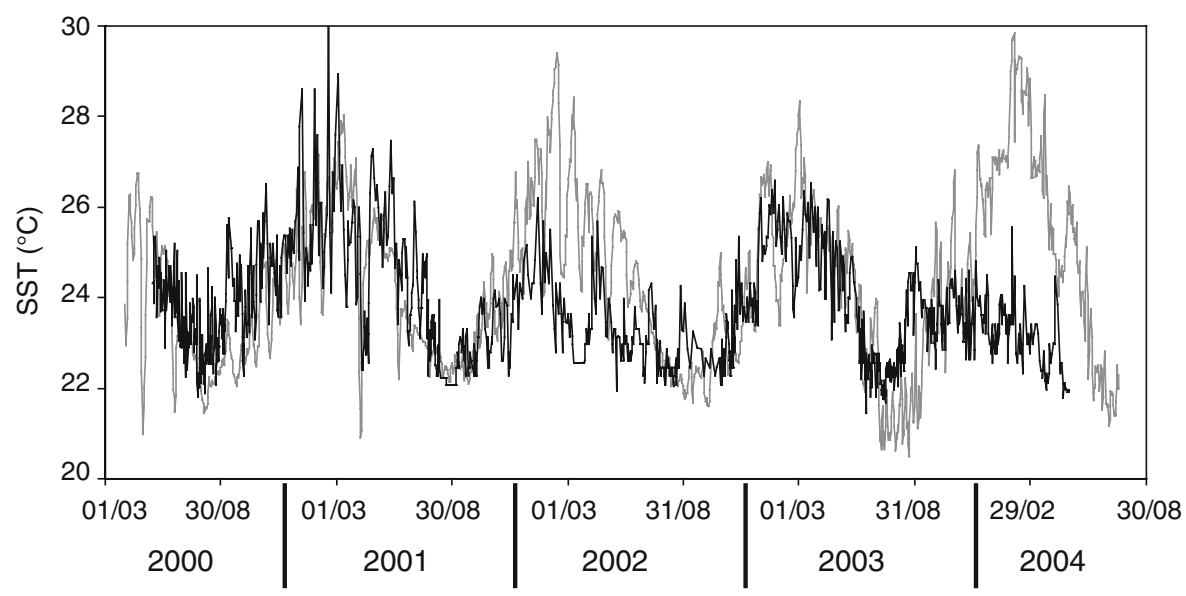

calculated $r^{2}$ are higher for the periods 2000-2001 $\left(r^{2}=44 \%\right)$ and $2002-2003\left(r^{2}=57 \%\right)$ than for the periods 2001-2002 $\left(r^{2}=26 \%\right)$ and 2003-2004 $\left(r^{2}=2 \%\right)$. Regarding the period 2001-2002, if the " $b$ " event is remove), the $r^{2}$ increases to reach the value of $42 \%$. The equation for the period 2002-2003 is $\mathrm{SST}=0.17 \times$ (growth increment thickness) +21.26 . The calculated SST reconstruction using this equation is shown on Fig. 6. On the whole record, mean calculated SST is of $23.5 \pm 1.2^{\circ} \mathrm{C}$ with a minimum of $21.4^{\circ} \mathrm{C}$ and a maximum of $30.3^{\circ} \mathrm{C}$.

\section{Discussion}

The reliability of H. hippopus $\delta^{18} \mathrm{O}_{\text {shell }}$ as a SST proxy

The $\delta^{18} \mathrm{O}_{\text {shell }}$ time-series obtained on the 4-year-old $H$. hippopus shell displays the SST changes with a good accuracy. The sharp pattern of $\delta^{18} \mathrm{O}_{\text {shell }}$ observed during the winters (Figs. 4, 5) is an artefact of sampling procedure; a greater amount of shell growth is sampled during reduced winter growth comparatively to summer higher growth (time-averaging).

An equation relating $\left(\delta^{18} \mathrm{O}_{\text {shell }}-\delta^{18} \mathrm{O}_{\mathrm{Sw}}\right)$ and SST is obtained for the period 2000-2003, during which SSS are available. Over this 3-year period, the equation has a lower $r^{2}$ than that obtained by Watanabe and Oba (1999) in the same species. This smaller $r^{2}$ might reflect the fact that this study displays a longer period of shell growth, 3 years compared to 1 year analysed by Watanabe and Oba (1999). In addition, to minimize the arbitrary anchoring of the $\delta^{18} \mathrm{O}_{\text {shell }}$ time-series, very few tie-points were selected, thus some time-shifting between the $\delta^{18} \mathrm{O}_{\text {shell }}$ and SST series might exist. The averaging of the SST data in accordance with the number of increments counted inside each stable isotope sampling groove may also have given some imprecision in the final equation. Nevertheless, year to year $r^{2}$ between SST and $\delta^{18} \mathrm{O}_{\text {shell }}$ are higher than that of the whole 2000-2003 period, except for 2002-2003. This period corresponds to the removal of the $H$. hippopus into the tank. The lower $r^{2}$ obtained for this year could thus reflect the stress endured by the animal during the transplantation and its adaptation to a new environmental setting. Indeed, the second $\delta^{18} \mathrm{O}_{\text {shell }}$ peak observed during the 2003 summer exactly corresponds to the period of removal of the specimen. However, even if the $r^{2}$ of the equation is lower than the one obtained by Watanabe and Oba (1999), the calculated seasonal SST amplitudes are at a $1^{\circ} \mathrm{C}$ margin of the instrumental SSTs. This precision is higher than that obtained with the Watanabe and Oba (1999) equation when applied to our $\delta^{18} \mathrm{O}_{\text {shell }}$ data. Consequently, the equation established here should be preferred for reconstruction of paleao-SST reconstructions using $H$. hippopus $\delta^{18} \mathrm{O}_{\text {shell }}$ analyses. This work further demonstrates that the $H$. hippopus shell is secreted in isotopic equilibrium with seawater. The SST equation we established accurately reproduces the seasonal SST amplitudes. This is of considerable interest for paleo-SST reconstruction using $H$. hippopus shells from fossil and archaeological settings.

Interpretation of shell growth mode in relation with environmental changes

\section{Relationship between shell growth and climatic parameters}

The current study shows for the first time a direct relationship between $H$. hippopus shell incremental growth and SSTs. For the period 2002-2003, almost $60 \%$ of the increment thickness changes can be explained by the SST variations. Nevertheless, the positive correlation between shell growth and SST is not completely consistent over the whole record. For the cycle 2 (2001-2002), a significant growth decrease is observed in March 2002 (b in Figs. 4, $5 b)$ that explains the poor $r^{2}$ between increment thickness and SST for this year. Regarding the recorded environmental parameters, no peculiar environmental change is 

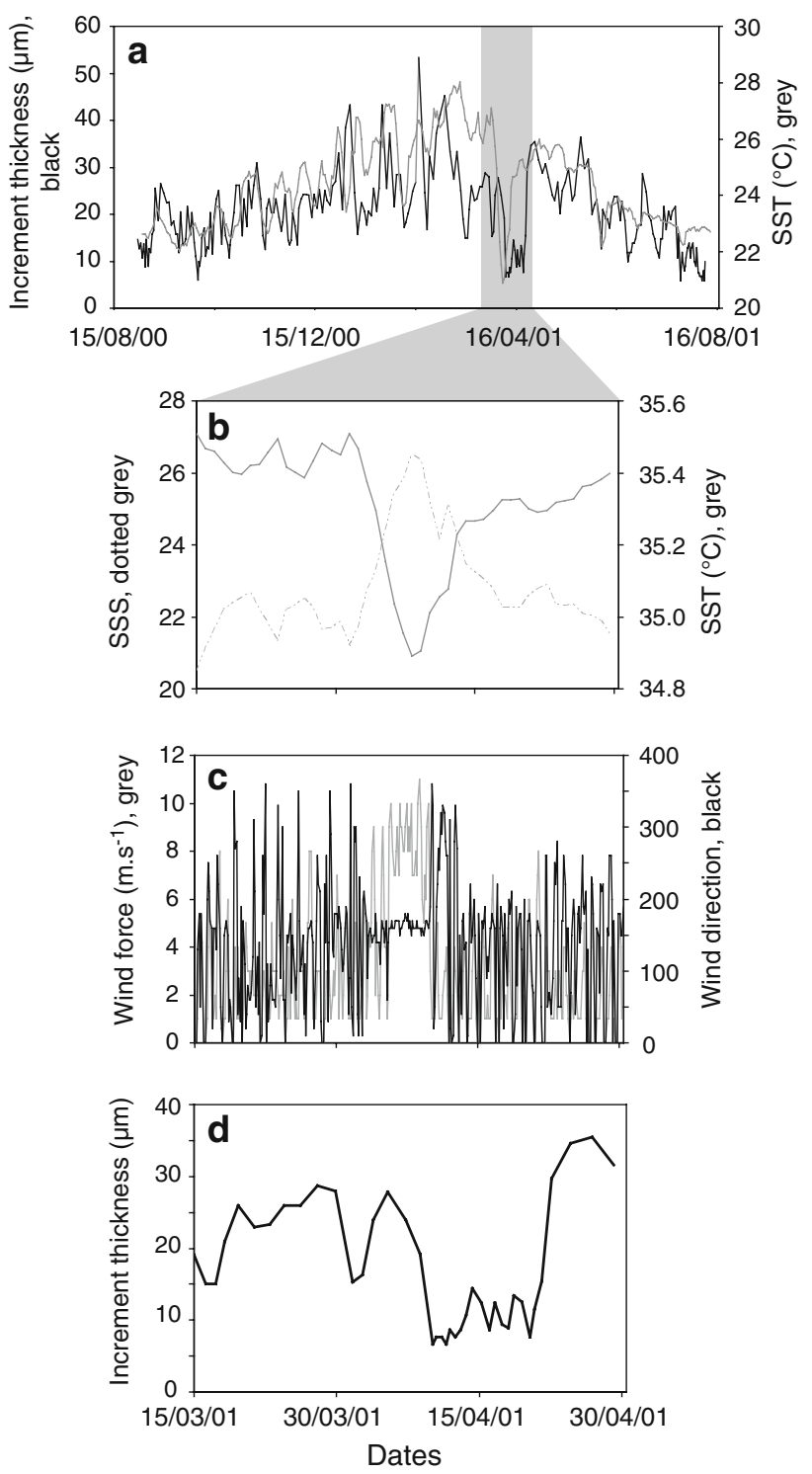

Fig. 7 The upwelling-related Hippopus hippopus shell growth decrease (event a in Figs. 4, 5b). a Shell increment thickness and SST for the 2000-2001 austral summer. b-d Enlargement of the April 2001 upwelling event. b SST and SSS record; c Wind force and direction; d Increment thickness

observed during this period. A similar observation can be made regarding the "c" growth decrease of the 2002-2003 cycle. Consequently, these growth decreases are more probably linked with the physiology (e.g., disease, reproduction) and/or non climatic stress (e.g., predators, food availability). No typical borings of sponges or algae, which are common bioeroders of giant clams (Ellis 2000), were evidenced, neither on the inside nor on the outside of the shell. The sexual maturity of $H$. hippopus is at 2 years (Shelley 1989) and is characterized by a decrease of 35$40 \%$ of the body weight during spawning (Shelley and Southgate 1988). Because the decrease "b" occurred during the third year of growth, and because a high energy is required during the spawning period, both events, "b" and "c", might be interpreted as reflecting the occurrence of reproduction events. Regarding the whole thinner increments of the last year of growth, the low $r^{2}$ between growth and SST could be interpreted as a difficult adaptation of the animal to the new environmental conditions of the tank. Indeed, it was shown that transplantation leads to growth rate decrease as shown in Mercenaria mercenaria (Rhoads and Pannella 1970). The energy percentage generally devoted to the shell growth was probably preferentially used for survival. So, due to physiological and/or non climatic stress, growth increment thickness changes can hardly be used as an accurate high-resolution SST proxy. Nevertheless, calculated SSTs using the sclerochronological record gives, whole period considered, mean, maximum and minimum SSTs at a $1{ }^{\circ} \mathrm{C}$ margin of the instrumental SSTs. Consequently, in case of diagenesis alteration that prevents geochemistry and sclerochronology study of $H$. hippopus shell could provide indication on the average, minimal and maximal past SSTs with a good accuracy.

\section{Identification of peculiar events}

The sclerochronological analysis performed in the $H$. hippopus shell also reveals a peculiar event characterized by a drastic, and quite short, shell growth decrease (event "a" in Figs. 4, 5b, 7). This event, which lasted from 5 to 22 April 2001, occurs shortly after important environmental conditions change (Fig. 7). Indeed, at the beginning of April 2001, the SST decreased (by $6^{\circ} \mathrm{C}$ ), the SSS and the wind forces increased (by 0.53 PSU and from $\sim 2$ to $9 \mathrm{~m} \mathrm{~s}^{-1}$ respectively), and the winds turned to a westward direction. These new drastically changed environmental conditions lasted almost 15 days and are characteristic of those inducing wind-driven upwelling event as described by Hénin and Cresswell (2005) and Alory et al. (2006). The start of the shell growth drop occurs $\sim 4$ days after the onset of the environmental condition leading to the upwelling. This lag could results from the different geographical location between the upwelling itself, outside the reef barrier, and the specimen, inside the lagoon. This lag could also be apparent, in relation to the calendar date assignment procedure. Nevertheless, the shell growth reduction is probably related to the stress undergone by the animal due to the upwelling-related decrease in SST (and/ or with the salinity increase). This interpretation is in agreement with the close relationship observed between the shell growth and the SST. The fact that our specimen recorded an outer-reef upwelling event in its shell proves that such an event has an impact inside the lagoon, as observed in corals (Montaggioni et al. 2006). Abrupt and short reductions in the $H$. hippopus shell growth could thus be used like indicators of high-intensity upwelling events. 
A study on $H$. hippopus shells, grown both in situ and in aquarium, is currently underway. This study, which involves an environmental monitoring particularly directed towards the record of productivity changes through the year, should give new information on the relation between upwelling (and its related environmental changes) and shell growth.

Acknowledgments We are grateful to C. Chilcott (University of Edinburgh; School of Geosciences) for his help to manage the stable isotope analyses. The living specimen and the tank monitoring were acquired in the framework of a Franco-Japanese collaboration. We thank J. Butscher (UMR LOCEAN, former UR Paléotropique, IRD Nouméa) for in situ sampling of the modern specimen and Claire Goiran for her help during the experimentation in tank. We are grateful to Météo France Nouvelle-Calédonie for providing environmental data (wind) and to David Varillon (lab. IRD «IMAGO »), LEGOS laboratory from IRD Nouméa and Zonéco program for providing the Thermosalinograph datasets monitored at Uitoé. Our thanks are extended to M. Lengaigne (IPSL/LOCEAN-UMR 7159) for useful discussion and to M. Elliot (University of Edinburgh; School of Geosciences) for her help in using the instrumental facilities from the Edinburgh University. This work is a contribution of the former Paléotropique team from IRD, now at the IPSL/LOCEAN-UMR 7159.

\section{References}

Aharon P (1983) 140,000-year isotope climatic record from raised coral reefs in New Guinea. Nature 304:720-723

Aharon P (1991) Recorders of reef environment histories: stable isotopes in corals, giant clams, and calcareous algae. Coral Reefs 10:71-90

Aharon P, Chappell J (1986) Oxygen isotopes, sea level changes and the temperature history of a coral reef environment in New Guinea over the last $10^{5}$ years. Palaeogeogr Palaeoclimatol Palaeoecol 56:337-379

Aharon P, Chappell J, Compston W (1980) Stable isotope and sealevel data from New Guinea supports Antarctic ice-surge theory of ice ages. Nature 283:649-651

Alory G, Vega A, Ganachaud A, Despinoy M (2006) Influence of upwelling, subsurface stratification, and heat fluxes on coastal sea surface temperature off southwestern New Caledonia. J Geophys Res 111:C07023. doi:07010.01029/02005JC003401

Ambariyanto, Hoegh-Guldberg O (1997) Effect of nutrient enrichment in the field on the biomass, growth and calcification of the giant clam Tridacna maxima. Mar Biol 129:635-642

Armendáriz M, Rosales I, Quesada C (2008) Oxygen isotope and Mg/ Ca composition of Late Viséan (Mississippian) brachiopod shells from SW Iberia: palaeoclimatic and palaeogeographic implications in northern Gondwana. Palaeogeogr Palaeoclimatol Palaeoecol 268:65-79

Barker RM (1964) Microtextural variation in pelecypod shells. Malacologia 2:69-86

Beck JW, Edwards RL, Ito E, Taylor FW, Recy J, Rougerie F, Joannot P, Henin C (1992) Sea-surface temperature from coral skeletal strontium/calcium ratios. Science 257:644-647

Bonham K (1965) Growth rate of giant clam Tridacna gigas at Bikini Atoll as revealed by radioautography. Science 149:300-302

Brigaud B, Pucéat E, Pellenard P, Vincent B, Joachimski MM (2008) Climatic fluctuations and seasonality during the Late Jurassic (Oxfordian-Early Kimmeridgian) inferred from [delta]180 of Paris Basin oyster shells. Earth Planet Sci Lett 273:58-67
Chappell J, Polach HA (1972) Some effects of partial recrystallisation on ${ }^{14} \mathrm{C}$ dating Late Pleistocene corals and molluscs. Quat Res 2:244-252

Corrège $\mathrm{T}$ (2006) Sea surface temperature and salinity reconstruction from coral geochemical tracers. Palaeogeogr Palaeoclimatol Palaeoecol 232:408-428

Ellis S (2000) Nursery and grow-out techniques for Giant Clams (Bivalvia: Tridacnidae). Center Trop Subtrop Aquac 143:1-99

Enmar R, Stein M, Bar-Matthews M, Sass E, Katz A, Lazar B (2000) Diagenesis in live corals from the Gulf of Aqaba. I. The effect on paleo-oceanography tracers. Geochim Cosmochim Acta 64: $3123-3132$

Gagan MK, Ayliffe LK, Beck JW, Cole JE, Druffel ERM, Dunbar RB, Schrag DP (2000) New views of tropical paleoclimates from corals. Quaternary Sci Rev 19:45-64

Goodwin DH, Flessa KW, Schöne BR, Dettman DL (2001) Crosscalibration of daily growth increments, stable isotope variation, and temperature in the Gulf of California bivalve mollusk Chione cortezi: implications for paleoenvironmental analysis. Palaios 16:387-398

Hendy EJ, Gagan MK, Lough JM, McCulloch M, deMenocal PB (2007) Impact of skeletal dissolution and secondary aragonite on trace element and isotopic climate proxies in Porites corals. Paleoceanography 22 doi:10.1029/2007PA001462

Hénin C, Cresswell GR (2005) Upwelling along the western barrier reef of New Caledonia. Mar Freshw Res 56:1005-1010

Henocque Y (1980) L'âge du bénitier Tridacna maxima (Mollusques-Bivalves) par examen des stries de croissance de sa coquille. Bull Soc Zool Fr 105:309-312

Jones DS (1983) Sclerochronology: reading the record of the molluscan shell. Am Sci 71:384-391

Jones DS, Williams DF, Romanek CS (1986) Life history of symbiont-bearing Giant Clams from stable isotope profiles. Science 231:46-48

Klumpp DW, Griffiths CL (1994) Contribution of phototrophic and heterotrophic nutrition to the metabolic and growth requirements of four species of giant clam (Tridacniadae). Mar Ecol Prog Ser 115:103-115

Lucas JS, Nash WJ, Crawford CM, Braley RD (1989) Environmental influences on growth and survival during the ocean-nursery rearing of giant clams, Tridacna gigas (L.). Aquaculture 80:45-61

McGregor HV, Gagan MK (2003) Diagenesis and geochemistry of Porites corals from Papua New Guinea: implications for paleoclimate reconstruction. Geochim Cosmochim Acta 67:2147-2156

Montaggioni LF, Le Cornec F, Corrège T, Cabioch G (2006) Coral barium/calcium record of mid-Holocene upwelling activity in New Caledonia, South-West Pacific. Palaeogeogr Palaeoclimatol Palaeoecol 237:436-455

Müller A, Gagan MK, McCulloch MT (2001) Early marine diagenesis in corals and geochemical consequences for paleoceanographic reconstructions. Geophys Res Lett 28:4471-4474

Ourbak T, Corrège $\mathrm{T}$, Malaizé $\mathrm{B}$, Le Cornec $\mathrm{F}$, Charlier $\mathrm{K}$, Peypouquet J-P (2006) A high-resolution investigation of temperature, salinity, and upwelling activity proxies in corals. Geochem Geophys Geosyst Q03013 doi:10.1029/2005GC001 064

Pannella G, MacClintock C (1968) Biological and environmental rhythms reflected in molluscan shell growth. J Paleontol 42: $64-80$

Pätzold J, Heinrichs JP, Wolschendorf K, Wefer G (1991) Correlation of stable oxygen isotope temperature record with light attenuation profiles in reef-dwelling Tridacna shells. Coral Reefs 10:65-69

Quinn TM, Taylor FW (2006) SST artifacts in coral proxy records produced by early marine diagenesis in a modern coral from 
Rabaul, Papua New Guinea. Geophys Res Lett 33:L04601. doi: 04610.01029/02005GL024972

Rhoads DC, Lutz RA (eds) (1980) Skeletal growth of aquatic organisms: biological records of environmental change. Plenum Press, New-York

Rhoads DC, Pannella G (1970) The use of molluscan shell growth patterns in ecology and paleoecology. Lethaia 3:143-161

Richardson CA (2001) Molluscs as archives of environmental changes. In: Gibson RN, Barnes M, Atkinson RJA (eds) Oceanogr Mar Biol Annu Rev 39:103-164

Romanek CS, Grossman EL (1989) Stable isotope profiles of Tridacna maxima as environmental indicators. Palaios 4:402-413

Rosewater J (1965) The family Tridacnidae in the Indo-Pacific. IndoPacific Mollusca 1:347-396

Schöne BR, Dunca E, Fiebig J, Pfeiffer M (2005a) Mutvei's solution: an ideal agent for resolving microgrowth structures of biogenic carbonates. Palaeogeogr Palaeoclimatol Palaeoecol 228:149-166

Schöne BR, Houk SD, Freyre Castro AD, Fiebig J, Oschmann W (2005b) Daily growth rates in shells of Arctica islandica: assessing sub-seasonal environmental controls on a long-lived bivalve mollusk. Palaios 20:78-92
Shelley CC (1989) Growth, sclerochronology and development of the Tridacnidae, with particular reference to Hippopus hippopus. Ph.D. thesis, James Cook University

Shelley CC, Southgate PC (1988) Reproductive periodicity and morphometry of Hippopus hippopus and Tridacna crocea. In: Copland JW, Lucas JS (eds) Giant clams in Asia and the Pacific. Australian Centre for International Agricultural Research, Canberra, pp $86-88$

Vincent DG (1994) The South Pacific Convergence Zone (SPCZ): a review. Mon Weather Rev 122:1949-1970

Watanabe T, Oba T (1999) Daily reconstruction of water temperature from oxygen isotopic ratios of a modern Tridacna shell using a freezing microtome sampling technique. J Geophys Res 104:20, $667-620,674$

Watanabe T, Suzuki A, Kawahata H, Kan H, Ogawa S (2004) A 60year isotopic record from a mid-Holocene fossil giant clam (Tridacna gigas) in the Ryukyu Islands: physiological and paleoclimatic implications. Palaeogeogr Palaeoclimatol Palaeoecol 212:343-354 